\title{
The Examination of the Social Integration Perceptions of Undergraduate Students
}

\author{
Habib Özgan ${ }^{1}$, Şahabettin Akşab ${ }^{2}$ \\ ${ }^{1}$ Assoc. Prof. Dr., Gaziantep University, Faculty of Education, Department of Educational Sciences, Turkey \\ ${ }^{2}$ Research Assistant, Gaziantep University, Faculty of Education, Department of Educational Sciences, Turkey \\ Correspondence: Habib Özgan, Assoc. Prof. Dr., Gaziantep University, Faculty of Education, Department of \\ Educational Sciences, Turkey
}

Received: January 24, 2018

doi:10.11114/jets.v6i3a.3155
Online Published: April 1, 2018

URL: https://doi.org/10.11114/jets.v6i3a.3155

\begin{abstract}
This study was aimed to determine the social integration perceptions of undergraduate students and to examine them in terms of certain variables. It was a descriptive study with survey methodology. The data were obtained using the Social Integration Scale. The study group consisted of 545 undergraduate students during the fall semester of 2016-2017 academic year. The research sample was determined using probability-based sampling techniques. SPSS 20.0 software package was used in data analysis. Mann Whitney U and Kruskal Wallis H-Tests were conducted to research data. According to the research results, it was revealed that undergraduate students had higher social integration perceptions in general. The research findings indicated that undergraduate students' perceptions of integration with the social environment differ significantly according to their departments, ages and income; their local integration perceptions according to the geographical region they reside and the occupation of mother; their educational integration perceptions according to their departments, ages and income; their normative-moral integration perceptions according to their departments and the educational degrees of parents.
\end{abstract}

Keywords: social integration, university, undergraduate students

\section{Introduction}

Education serves as a social institution to realize and enhance the economic, social and cultural expectations of the society. The reason for existence of education is the social necessity. Education has several roles such as learning and development from the individual aspect and meeting several needs in various areas in order to be able to sustain the existence of the society from the societal aspect (Aslan, 2001). The high level of educational expectations of individuals and societies has created diversity and confusion about the purposes and functions of education (Hoşgörür and Taştan, 2006). It is fundamental to understand the functions of education properly for the progress of the educational procedure. It is the way to achieve the goals that have been intended. Therefore, it will not be wrong to call the educational functions as the sea lantern of the educational staff (Doğan, 2014). From this point of view, the functions of education can be grouped under two main headings as explicit and implicit.

The explicit functions of education include the acquisition of the intended behaviors and attitudes by the individuals through educational procedure (Dinçer, 2003). They were integrated into each grade levels by the ministry through the curricula of the courses. It is clear from educational procedure in practice that the explicit functions of education have philosophical, economic, political, personal and social roles. In this context, the social functions of education are alleged to be the transference of the cultural heritage, the socialization of the individual, and the cultivation of innovative individuals. The educational systems all over world aim to maintain friendship and harmony in society by cultivating individuals who know, appreciate and develop their own cultures (Özdemir, 2011; Beşirli, 2016). That is a quite important process to enable social integration. The education systems are obliged to prepare the people they address to be integrated with their community (Gişi, et al, 2012).

'Social integration is the broadening of the feeling of 'us' (party, group, etc.) in the narrow sense to the feeling of "us" at the societal level. According to another definition, social integration is the state of the social groups' consciousness level of existence being fit with the integration in the society' (Erkal, 2004:6). It is too hard to provide full social integration for any kind of social order. Otherwise, evolution and development would become impossible. That's why, integration is 
a relative state of affair without certain templates. It is not possible to eliminate differences existing within society through social integration. On the contrary, it is effective on the orientation of these differences and putting them in harmony and order (Tezcan, 1995).

Social integration incorporates a series of social events. It can be asserted that the most important process for the realization of integration is socialization. The factors that contribute to the realization of social integration are the individuals' working in partnership with others, competing or experiencing the processes of harmony and conflict in a social environment. It starts with the birth of human and covers all the period to death (Güney, 2008). The acceptance of social norms, values, beliefs, habits, tendencies and behavioral models of social life by the individual as a social entity takes place through politics, education, economy, culture and other social institutions within the process of socialization (Dursun 2012; İçli 2005; Özpolat, 2009). Educational institutions and processes also play important roles in the realization of social integration as much as the institutions ofcontrol and audit. The socialization of individuals is the main function of education in social integration (Şimşek and Şimşek, 2010).

The factors facilitating social integration can be examined under two main headings. They can be called essential and subsidiary factors. There are three main characteristics of the essential factors. First of all, social integration would be easier to realize by gathering around common values. Common values and norms, even at a minimum level, are fundamental in building up a society. They contain generalized understandings of the people in that society and are considered to be the main factors in ensuring socio-cultural integration. The second main element is job sharing. It is of great importance in terms of the nature of work and for those in question. The third one is the participation of people in different groups with different cultural identities in a pluralist structure. Individuals play different roles in different social environments, and they usually perform these roles according to the wishes of others. The subsidiary factors can be called as the elements that support social integration within the framework of context and circumstances. External pressures and threats that people are exposed to in society are great examples. To exemplify, the social response that the community react against the threats of enemy during the war. Secondly, statute differences, sanctions and rules of law may have functions in terms of social integration. The interdependence of people with mutual interest facilitates the establishment of a socially integrated environment. The communities in society pursue different interests. Although they are different to a great extent, they are interdependent to look after their interests (Türkkahraman and Tutar, 2009).

It can be observed that the practices aimed to enhance social integration in educational organizations are inadequate especially in universities where the young with different cultural backgrounds from different geographical regions come together. Therefore, the determination of social integration perceptions is thought to be highly effective for the studies to be conducted to strengthen social integration. The strengthening of social integration will foster the initiatives among the young, their social and economic skills and their participation in the development of the country. This will also allow them to come together and interact each other (http://www.gap.gov.tr/Turkish/Basinbil/Bbil2006/bb255.html; erişim 18.10.2011).

\subsection{The Purpose of the Study}

The purpose of the study is to determine the social integration perceptions of undergraduate students and to find out whether there are statistically meaningful differences in terms of certain variables.

The sub-research problems can be listed as follows:

1. What are the social integration perceptions of undergraduate students?

2. Do the general social integration perceptions of undergraduate students differ statistically significantly according to the variables of gender, class, department, age, academic level of achievement, the place and the geographical region they reside, the income of their family, the educational degrees of their parents and the occupations of their parents?

\section{Method}

\subsection{Research Methodology}

It was a descriptive study with survey methodology. As the quantitative research methodology is structured and planned, the nature of the data is strong and trustworthy (Sönmez and Alacapınar, 2016). At the very beginning of these kind of studies, a universe is determined. In cases where the number of participants is quite high, the sample is determined from the universe. The sample allows to obtain a general view about the universe. This research is a relational study using the screening model. The relational studies enable to understand important situations by examining the relationships between different variables (Fraenkel, Wallen and Hyun, 2012). These studies aim to understand whether there is a dependent variance between two or more variables, and to find out the degree if that is the case (Karasar, 2009). Descriptive research data were analyzed using descriptive statistics. SPSS 20.0 software package was used in data analysis. Variance analyzes were conducted to determine the social integration perceptions of undergraduate students. 


\subsection{Universe and Sample}

The research sample was determined using stratified sampling technique among probability-based sampling techniques. The universe of the study consisted of 545 undergraduate students enrolled at the fall semester of 2016-2017 academic year. As the study was conducted on actively studying undergraduate students, it was necessary to use a stepwise methodology to specify the sampling group. A four-step method was used to determine the sample. The steps were as follows:

1. In the first step, the students in the universe were divided into 3 separate clusters according to cluster sampling method: social sciences, physical sciences and art / sports based departments.

2. In the second step, the departments were specified from each of 3 different clusters in accordance with the accessibility technique.

3. In the third step, the departments were divided into 5 different layers by stratified sampling method: $1^{\text {st }}, 2^{\text {nd }}, 3^{\text {rd }}$, $4^{\text {th }}$ grade students and the alumni. Drawing of lots was used in case of several branches.

4. At the final step, 545 students were included in the sample group on the basis of voluntary participation among those who were studying at specified branches and the research data were obtained.

\subsection{Instruments of the Study}

In this study, the Social Integration Scale was used to collect data. The scale has 6 sub-dimensions including integration with social environment, local integration, familial integration, educational integration, national integration and normative-moral integration. The Social Integration Scale used in this study was developed by Şimşek and Şimşek (2013). The ratings of items on a 5-point Likert-type scale are 'Totally Disagree (1)', 'Disagree (2)', 'Undecided (3)', 'Agree (4)', and 'Totally Agree (5)'. The scale consists of 47 items. The scale reliability coefficient was calculated as 0.87. It indicates that the scale is valid and reliable. The options and the ratings of scores for the items on the scale are as follows:

Table 2.1. The Ratings of Scale Items

\begin{tabular}{lll}
\hline Options & Score & Ratings \\
\hline Totally Agree & 5 & $4.20-5.00$ \\
\hline Agree & 4 & $3.40-4.19$ \\
\hline Undecided & 3 & $2.60-3.39$ \\
\hline Disagree & 2 & $1.80-2.59$ \\
\hline Totally Disagree & 1 & $1.00-1.79$ \\
\hline
\end{tabular}

2.4 Data Collection and Analysis

SPSS 20.0 software package was used to analyze research data. Variance analyzes were conducted to determine the social integration perceptions of undergraduate students. The $\mathrm{p}$ values in the results indicate that the data set is not normally distributed $(\mathrm{p}=, 006, \mathrm{p}<, 05)$.

Table 2.2. Test Results of Normality of Social Integration Scores

\begin{tabular}{lcl}
\hline Values & Social Integration Scale \\
\hline $\mathrm{N}$ & $\overline{\mathrm{x}}$ & 545 \\
Normal Parameters & $\mathrm{sd}$ & 176,28 \\
Kolmogorov-Smirnov Z & & 25,31 \\
$\mathrm{p}$ & & 006 \\
\hline
\end{tabular}

As the obtained data were not normally distributed, it was decided to use non-parametric analysis methods. In variance analyses, Mann Whitney U-Test was used for two categorical variables (gender) and Kruskal Wallis H-Test was used for three or more categorical variables (class, department, age, academic level of achievement, the place and the geographical region the students reside, the income of the family, the educational degrees of the parents and the occupations of the parents).

\section{Findings}

The mean of the participants' social integration perceptions was calculated as 3.75. The finding of the students' social integration perceptions referred to high level of score in general. The research results revealed that general social integration perceptions of undergraduate students didn't differ statistically significantly according to the variables of gender, class, department, age, academic level of achievement, the place and the geographical region the students reside, 
the income of the family, the educational degrees of the parents and the occupations of the parents. The means of the sub-dimensions were determined as integration with social environment $(\bar{X}=3.79)$, local integration $(\bar{X}=3.00)$, familial integration $(\bar{X}=3.97)$, educational integration $(\bar{X}=2.81)$, national integration $(\bar{X}=4.25)$, normative-moral integration $(\bar{X}=4.42)$. The lowest integration observed in the educational dimension while the highest integration was found in the normative-moral dimension.

\subsection{Are There Statistically Significant Differences Between Integration With Social Environment Scores of Undergraduate Students And Independent Variables?}

The research results revealed that integration with social environment perceptions of the participants didn't differ statistically significantly according to the variables of gender, class, academic level of achievement, the place and the geographical region they reside, the educational degrees of their parents and the occupations of their parents while significant differences were observed for the variables of departments, age and the income of their family.

Table 3.1. Kruskal Wallis-H Test Results about Integration with Social Environment Scores According to Department

\begin{tabular}{lllllll}
\hline Score & Department & $N$ & $\bar{x}_{\text {rank }}$ & $x^{2}$ & $d f$ & $p$ \\
\multirow{2}{*}{ Integration } & Physical Sciences & 225 & 244,92 & & & \\
with Social & Social Sciences & 276 & 284,60 & \multirow{2}{*}{14,02} & 2 & \multirow{2}{*}{00} \\
Environment & Art / Sports & 41 & 329,22 & & & \\
& Total & 542 & & & & \\
\hline
\end{tabular}

According to the results of statistical analysis in Table 3.1, there was a significant difference between integration with social environment scores and the departments of the students $\left(x^{2}=14,02 ; \mathrm{df}=2 ; \mathrm{p}=, 00 ; \mathrm{p}<, 05\right)$. The examination of the mean ranks suggested that the students with the highest integration with social environment scores were the students of Art / Sports Sciences and it was followed by the ones of social sciences and physical sciences respectively.

Table 3.2. Kruskal Wallis-H Test Results about Integration with Social Environment Scores According to Age

\begin{tabular}{lllllll}
\hline Score & Age & $N$ & $\overline{\tilde{N}}$ Tank & $x^{2}$ & $d f$ & $p$ \\
\hline \multirow{2}{*}{ Integration } & $17-20$ & 129 & 236,29 & & & \\
with Social & $21-23$ & 256 & 278,64 & 7,02 & 2 & \multirow{2}{*}{, 03} \\
Environment & 24 and over & 149 & 275,37 & & & \\
& Total & 534 & & & & \\
\hline
\end{tabular}

According to Table 3.2, there was a significant difference between integration with social environment scores and the ages of the students $\left(x^{2}=7,02 ; \mathrm{df}=2 ; \mathrm{p}=, 03 ; \mathrm{p}<, 05\right)$. The examination of the mean ranks revealed that the students with the highest integration with social environment scores were the students between 21-23 ages while the ones with the lowest integration with social environment scores were the ones between 17-20.

Table 3.3. Kruskal Wallis-H Test Results about Integration with Social Environment Scores According to the Income of the Family

\begin{tabular}{|c|c|c|c|c|c|c|}
\hline Score & Income & $N$ & A Tank & $x^{2}$ & $d f$ & $p$ \\
\hline \multirow{4}{*}{$\begin{array}{l}\text { Integration } \\
\text { with Social } \\
\text { Environment }\end{array}$} & $0-1500 €$ & 164 & 251,19 & \multirow{4}{*}{6,58} & \multirow{4}{*}{2} & \multirow{4}{*}{,04 } \\
\hline & $1500-3000 €$ & 215 & 255,15 & & & \\
\hline & $3000 €$ and over & 148 & 291,05 & & & \\
\hline & Total & 527 & & & & \\
\hline
\end{tabular}

According to Table 3.3, there was a significant difference between integration with social environment scores and the income of the students' families ( $\left.x^{2}=6,58 ; \mathrm{df}=2 ; \mathrm{p}=, 04 ; \mathrm{p}<, 05\right)$. The examination of the mean ranks put forward that integration with social environment scores and the income of the students' families increased in direct proportion.

\subsection{Are There Statistically Significant Differences Between Local Integration Scores of Undergraduate Students and Independent Variables?}

The research results suggested that local integration perceptions of the participants didn't differ statistically significantly according to the variables of gender, class, department, age, the income of the family, academic level of achievement, the place the students reside, the educational degrees of the parents and the occupations of the fathers while significant differences were observed for the variables of the geographical region the students reside and the occupations of the mothers. 
Table 3.4. Kruskal Wallis-H Test Results about Local Integration Scores According to the Geographical Region

\begin{tabular}{lllllll}
\hline Score & Geographical Region & $N$ & $\overline{\mathbf{X}}$ rank & $x^{2}$ & $d f$ & $p$ \\
\hline \multirow{2}{*}{$\begin{array}{l}\text { Integration } \\
\text { with Social }\end{array}$} & Aegean & 6 & 249,50 & & & \\
Environment & 9 & 166,83 & & & \\
& Black Sea & 7 & 317,86 & & & \\
& Central Anatolia & 16 & 228,94 & & & \\
& Eastern Anatolia & 16 & 254,91 & & & \\
& Southeastern Anatolia & 383 & 287,17 & & & \\
& Mediterranean & 105 & 230,50 & 17,19 & 6 &, 00 \\
& Total & 542 & & & & \\
\hline
\end{tabular}

According to the results of statistical analysis in Table 3.4, there was a significant difference between local integration scores and the geographical region the participants reside $\left(x^{2}=17,19 ; \mathrm{df}=6 ; \mathrm{p}=, 00 ; \mathrm{p}<, 05\right)$. The examination of the mean ranks implied that the students with the highest local integration scores resided in the Black Sea Region while the ones with the lowest local integration in the Marmara Region.

Table 3.5. Kruskal Wallis-H Test Results about Local Integration Scores According to the Educational Degrees of the Parents

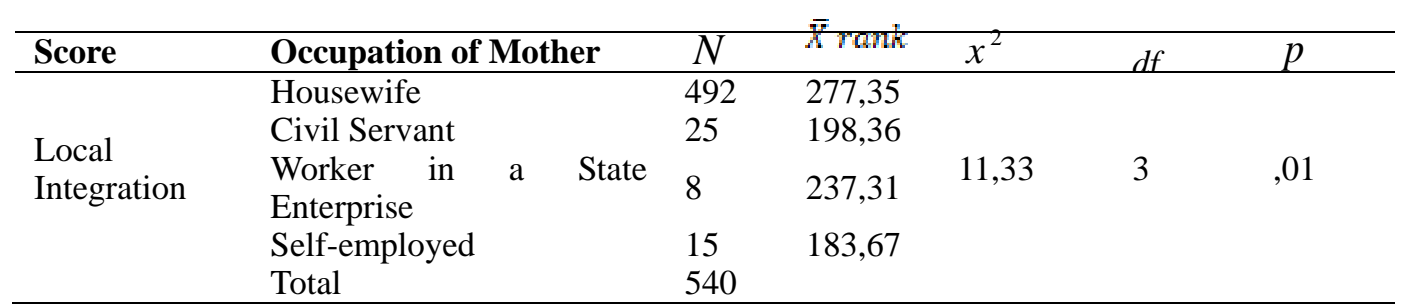

According to the Table 3.5, there was a significant difference between local integration scores and the occupations of the mothers $\left(x^{2}=11,33 ; \mathrm{df}=3 ; \mathrm{p}=, 01 ; \mathrm{p}<, 05\right)$. The examination of the mean ranks demonstrated that the students whose mothers were housewives were the participants with the highest local integration scores while the lowest local integration scores belonged to the students whose mothers were self-employed.

3.3 Are There Statistically Significant Differences Between Familial Integration Scores of Undergraduate Students and Independent Variables?

It was concluded that there were no significant differences between familial integration perceptions of the participants and the variables of gender, class, department, age, academic level of achievement, the place and the geographical region the students reside, the income of the family, the educational degrees of the parents and the occupations of the parents.

3.4 Are There Statistically Significant Differences Between Educational Integration Scores of Undergraduate Students and Independent Variables?

The research results revealed that educational integration perceptions of the participants didn't differ statistically significantly according to the variables of gender, department, academic level of achievement, the place and the geographical region the students reside, the educational degrees of the parents and the occupations of the parents while significant differences were observed for the variables of class, age and the income of the family,

Table 3.6. Kruskal Wallis-H Test Results about Educational Integration Scores According to Class

\begin{tabular}{|c|c|c|c|c|c|c|}
\hline Score & Class & $N$ & й rank & $x^{2}$ & $d f$ & $p$ \\
\hline \multirow{6}{*}{$\begin{array}{l}\text { Educational } \\
\text { Integration }\end{array}$} & $1^{\text {st }}$ grade & 29 & 361,47 & & & \\
\hline & 2 st grade & 99 & 215,46 & & & \\
\hline & 3 st grade & 73 & 265,08 & & & \\
\hline & 4 st grade & 239 & 262,95 & & & \\
\hline & Alumni & 100 & 320,62 & 33,18 & 4 &, 00 \\
\hline & Total & 540 & & & & \\
\hline
\end{tabular}


According to Table 3.7, there was a significant difference between educational integration scores and the class ( $x^{2}$ $=33,18 ; \mathrm{df}=4 ; \mathrm{p}=, 00 ; \mathrm{p}<, 05)$. The examination of the mean ranks implied that the students with the highest educational integration scores were the freshmen while the ones with the lowest educational integration were the sophomores.

Table 3.7. Kruskal Wallis-H Test Results about Educational Integration Scores According to Age

\begin{tabular}{lllllll}
\hline Score & Age & $N$ & $\bar{x}$ rank & $x^{2}$ & $d f$ & $p$ \\
\hline \multirow{3}{*}{ Educational } & $21-23$ & 129 & 251,21 & & & \\
Integration & 24 and over & 256 & 251,98 & & & \\
& Total & 149 & 308,27 & & 2 &, 00 \\
& & 534 & & & &
\end{tabular}

According to Table 3.7, there was a significant difference between educational integration scores and the ages of the students $\left(x^{2}=14,45 ; \mathrm{df}=2 ; \mathrm{p}=, 00 ; \mathrm{p}<, 05\right)$. The examination of the mean ranks put forward that educational integration scores and the ages of the students increased in direct proportion.

Table 3.8. Kruskal Wallis-H Test Results about Educational Integration Scores According to the Income of the Family

\begin{tabular}{|c|c|c|c|c|c|c|}
\hline Score & Income & $N$ & Xrank & $x^{2}$ & $d f$ & $p$ \\
\hline \multirow{4}{*}{$\begin{array}{l}\text { Educational } \\
\text { Integration }\end{array}$} & $0-1500 €$ & 164 & 283,18 & \multirow{4}{*}{6,33} & \multirow{4}{*}{2} & \multirow{4}{*}{, 04} \\
\hline & $1500-3000 €$ & 215 & 265,91 & & & \\
\hline & $3000 €$ and over & 148 & 239,98 & & & \\
\hline & Total & 527 & & & & \\
\hline
\end{tabular}

According to Table 3.8, there was a significant difference between educational integration scores and the income of the students' families $\left(x^{2}=6,33 ; \mathrm{df}=2 ; \mathrm{p}=, 04 ; \mathrm{p}<, 05\right)$. The examination of the mean ranks demonstrated that there was an inverse proportion between educational integration scores and the income of the students' families. That is, the more the income was, the less the educational integration scores were observed.

\subsection{Are There Statistically Significant Differences Between National Integration Scores of Undergraduate Students and Independent Variables?}

It was concluded that there were no significant differences between national integration perceptions of the participants and the variables of gender, class, department, age, academic level of achievement, the place and the geographical region the students reside, the income of the family, the educational degrees of the parents and the occupations of the parents.

\subsection{Are There Statistically Significant Differences Between Normative-Moral Integration Scores of Undergraduate Students and Independent Variables?}

The research results revealed that normative-moral integration perceptions of the participants didn't differ statistically significantly according to the variables of gender, class, age, the income of the family, academic level of achievement, the place and the geographical region the students reside and the occupations of the parents while significant differences were observed for the variables of department and the educational degrees of the parents.

Table 3.9. Kruskal Wallis-H Test Results about Normative-Moral Integration Scores According to Department

\begin{tabular}{lllllll}
\hline Score & Department & $N$ & X rank & $x^{2}$ & $d f$ & $p$ \\
\hline \multirow{3}{*}{ Normative-Moral } & Physical Sciences & 225 & 252,32 & & & \\
Integration & Social Sciences & 276 & 282,64 & & &, 04 \\
& Arts /Sports & 41 & 301,71 & & & \\
& Total & 542 & & & & \\
\hline
\end{tabular}

According to the results of statistical analysis in Table 3.9, there was a significant difference between normative-moral integration scores and the departments of the students $\left(x^{2}=6,41 ; \mathrm{df}=2 ; \mathrm{p}=, 04 ; \mathrm{p}<, 05\right)$. The examination of the mean ranks suggested that the participants with the highest normative-moral integration scores were the students of Art / Sports Sciences and it was followed by the ones of social sciences and physical sciences respectively. 
Table 3.10. Kruskal Wallis-H Test Results about Normative-Moral Integration Scores According to Educational Degree of the Mothers

\begin{tabular}{|c|c|c|c|c|c|c|}
\hline Score & $\begin{array}{l}\text { Educational Degree of } \\
\text { Mothers }\end{array}$ & $N$ & $\bar{X}$ rank & $x^{2}$ & $d f$ & $p$ \\
\hline \multirow{4}{*}{$\begin{array}{l}\text { Normative-Moral } \\
\text { Integration }\end{array}$} & Primary/Secondary & 417 & 280,38 & \multirow{4}{*}{7,00} & \multirow{4}{*}{2} & \multirow{4}{*}{, 03} \\
\hline & High School & 93 & 255,31 & & & \\
\hline & Undergraduate/Postgraduate & 33 & 213,17 & & & \\
\hline & Total & 543 & & & & \\
\hline
\end{tabular}

According to Table 3.10, there was a significant difference between normative-moral integration scores and the educational degrees of the participants' mothers $\left(x^{2}=7,00 ; \mathrm{df}=2 ; \mathrm{p}=, 03 ; \mathrm{p}<, 05\right)$. The examination of the mean ranks showed that the more the educational degrees of the participants' mothers were, the less the normative-moral integration scores were observed.

Table 3.11. Kruskal Wallis-H Test Results about Normative-Moral Integration Scores According to Educational Degrees of the Fathers

\begin{tabular}{lllllll}
\hline Score & $\begin{array}{l}\text { Educational Degree of } \\
\text { Fathers }\end{array}$ & $N$ & $\overline{\tilde{N}}$ rank & $x^{2}$ & $d f$ & $p$ \\
\hline \multirow{3}{*}{ Normative-Moral } & Primary/Secondary & 301 & 290,02 & & & \\
Integration & High School & 140 & 254,08 & & & \multirow{2}{*}{01} \\
& Undergraduate/Postgraduate & 102 & 243,43 & & 2 & \\
& Total & 543 & & & &
\end{tabular}

According to Table 3.11, there was a significant difference between normative-moral integration scores and the educational degrees of the participants' fathers $\left(x^{2}=9,34 ; \mathrm{df}=2 ; \mathrm{p}=, 01 ; \mathrm{p}<, 05\right)$. The examination of the mean ranks revealed that the more the educational degrees of the participants' fathers were, the less the normative-moral integration scores were observed.

\section{Conclusion and Discussion}

The research results indicated that the social integration perceptions of undergraduate students are in the level of "I agree" that is high. It was observed that the perceptions of integration with the social environment and educational institutions, where most of the students spend their time, are lower than the other sub-dimensions. It implied that the social environment and educational institutions were unable to meet the expectations and requests of the students decently. In a similar vein, a recent survey on high school students in the Southeastern Anatolia Region revealed that the young' levels of integration with social environment and their school were relatively low (Şimşek and Şimşek, 2013). According to the research findings, it was also supported by the fact that the items with the lowest means among the 47-item scale which were "I am satisfied with today's education system $(\bar{X}=1.71)$ ", "The school I study gives me the opportunity to use my skills ( $\overline{\bar{X}}=2.42)$ ", "Even if I had the opportunity to live elsewhere, I prefer staying here $(\bar{X}=2.45)$ ", "There is a strong solidarity among our relatives $(\bar{X}=2.93)$ ", "I am satisfied with the lessons and their contents in this school $(\bar{X}=2.94)$ ".

It was concluded that familial and local integration perceptions of the students were above the average. It can be interpreted that university students had a strong sense of familial and local commitment. Akın and Ceyhan's (2005) finding was in similar vein in that the students with a high level of perceived social support by their parents had a high level of self-acceptance.

According to the research results, the normative-moral and national integration perceptions of university students were found to be quite high. It implied that the university students had a sense of respect for the members of other religions, they found religious themes meaningful, they developed national consciousness and they were united around common values with the society. The research result of Gökçe et al. (2011) revealed that the young are mostly integrated around religious themes and that there was a minimum difference between their views on these kind of issues. According to the research findings, it was also supported by the fact that the items with the highest means among the 47 -item scale which were "Everyone's religious beliefs must be respected $(\bar{X}=4.70)$ ", "I am delighted to be a member of my family $(\bar{X}=4.62)$ ", "Our national anthem symbolizes the social integrity $(\bar{X}=4.61)$ ", "Being with my family makes me happy $(\bar{X}=4.60)$ ", "Moral values are important for social life $(\bar{X}=4.59)$ ".

A significant difference was observed between the departments the students they studied and the sub-dimensions of 
integration with social environment and normative-moral integration. It was concluded that the students with the highest perception of integration in normative-moral and social environment dimensions were the students in sports / art departments among the clusters of sports / arts, social sciences and physical sciences. Filiz (2010) found that the young who did sports, socialize easily despite their no matter how different they were personally, and that the sport had a socially integrative role. This finding supported the research at hand.

According to the research results, there was a significant relationship between the ages of the students and the perceptions of integration with social environment and educational integration. Meanwhile, a significant difference was observed between the local integration perceptions of university students and the geographical region they resided. The examination of the mean ranks suggested that the students with the highest local integration resided in the Black Sea Region while the ones with the lowest local integration in the Marmara Region. It can be argued that it was resulted in low levels of local integration perceptions as the Marmara's being the most immigrant-receiving region domestically. Similarly, it was established that immigrants may experience integration problems due to the influence of contemptuous and dismissive attitudes and behaviors of local people against the immigrants who could not internalize city life (Güven, 2016).

It was found that there was a meaningful relationship between the class that the students study and the educational integration perceptions. It can be argued that the freshmen's lowest perceptions of educational integration were due to the fact that they were in the adaptation period to the school.

The research results revealed a meaningful relationship between the income of the family and the perceptions of integration with social environment and educational integration. The higher level of income meant the higher perceptions of integration with social environment but the less educational integration. The examination of the relationship between occupations of the mothers and local integration perceptions, it was concluded that the participants whose mothers were housewives were integrated locally better than the other sub-groups.

Research findings indicated significant relationships between the education degrees of parents and normative-moral integration perceptions. As the parents' educational degrees increased, normative-moral integration decreased. It can be inferred that low-educated family children can internalize normative and moral values more easily.

\section{Recommendations}

1. According to the research results, although general social integration perceptions of undergraduate students were found to be high, it has been concluded that educational integration perceptions were low. Therefore, it may improve the process to reorganize the main functions, aims, visions and missions of the educational institutions by considering the expectations and requests of the students.

2. It was concluded that local integration perceptions of undergraduate students were the second lowest sub-dimension considering the sub-group means. The organization of incentive social activities and the incorporation of youth centers in various facilities will considerably contribute to the enhancement of local integration perceptions.

\section{References}

Akin, D., \& Ceyhan, E. (2005). Resmi ve ozel genel lise ogrencilerinin ailelerinden, arkadaslarindan ve ogretmenlerinden algiladiklari sosyal destek duzeyleri acisindan kendini kabul duzeylerinin incelenmesi. Anadolu Universitesi Sosyal Bilimler Dergisi, 5(2), 69-88.

Alacapinar F. G., \& Sonmez, V. (2016). Bilimsel arastirma yontemleri. Ani Yayincilik, Ankara.

Aslan, A. K. (2001). Egitimin toplumsal temelleri. Balikesir Universitesi Sosyal Bilimler Dergisi, 5, 16-30.

Bahcesehir Universitesi, Stratejik Arastirmalar Merkezi, "Dogu ve guneydogu anadolu bolgeleri sosyo-ekonomik ve sosyo-politik yapi arastirmasi ve dogu ve guneydogu anadolu bolgelerinden en fazla goc almis olan illerin sosyo-ekonomik ve sosyo-politik yapi arastirmasi: Sorunlar, beklentiler ve cozum onerileri”, Proje Raporu, Aralik 2009, Istanbul.

Besirli, H. (2016). Bireyin toplumsallasmasi surecinde spor. International Journal of Cultural and Social Studies (IntJCSS), 2(1), 25-31.

Dincer, M. (2003). Egitimin toplumsal degisme surecindeki gucu. Ege Egitim Dergisi, 3(1), 102-112.

Dogan, S. (2014). Egitim bilimine giris. C. T. Ugurlu (Ed.). Ankara: Egiten Kitap.

Dursun, D. (2012). Siyaset bilimi. Istanbul: Beta Yayinlari.

Erkal, M. (2004). Sosyoloji. Istanbul: Der Yayinlari. 
Filiz, Z. (2010). Universite ögrencilerinin sosyallesmesinde spora katilimin degerlendirilmesi. Beden Egitimi ve Spor Bilimleri Dergisi, 3, 192-203.

Fraenkel, J., Wallen, N., \& Hyun, H. (2012). How to design and evaluate research in education, (8th ed.), New York: McGraw-Hill.

Gisi, E., Sezgin, F., \& Pakel, M. (2012). Turk milli egitim sistemi Turkiye'nin sorunlarina ne kadar duyarli?. Sosyal ve Beseri Bilimler Dergisi, 4(2), 99-109.

Guney, S. (2008). Davranis bilimleri. Ankara: Nobel Yayinlari.

Guven, S. (2016). Goc, cevre ve iletisim. H. Z. Sarikaya ve digerleri (Ed.). International Symposium on Environment and Morality (s. 326-335) icinde. Alanya, Turkiye

Hosgorur, V., \& Tastan, N. (2006). Egitim bilimine giris. S. S. Ercetin ve N. Tozlu (Ed.). Ankara: Hegem Yayinlari.

Icli, G. (2005). Sosyolojiye giris. Ankara: Ani Yayincilik.

Karasar, N. (2009). Bilimsel arastırma yontemi. Ankara: Nobel Yayin Dagitim.

Ozdemir, S. M. (2011). Toplumsal degisme ve kuresellesme baglaminda egitim ve egitim programlari: Kavramsal bir cozumleme. Ahi Evran Universitesi Egitim Fakultesi Dergisi, 12(1), 85-110.

Ozpolat, A. (2009). Demokratik vatandaslik-birlikte yasama kulturu. Hegem Yayinlari, Ankara.

Simsek, A. S., \& Simsek, H. (2013). Guneydogu anadolu bolgesindeki lise ogrencilerinde sosyal butunlesme duzeyi. National Education, 198, 73-96.

Tezcan, M. (1995). Sosyolojiye giris. A.U. Basimevi, Ankara.

Turkkahraman, M., \& Tutar, H. (2009). Sosyal degisme, butunlesme ve cozulme baglaminda toplumda farkli kultur ve anlayislarin yeri ve onemi. Uluslararasi Alanya Isletme Fakultesi Dergisi, 1(1), 1-16. www.gap.gov.tr/Turkish/Basinbil/Bbil2006/bb255.html; erisim 18.10.2011).

\section{Copyrights}

Copyright for this article is retained by the author(s), with first publication rights granted to the journal.

This is an open-access article distributed under the terms and conditions of the Creative Commons Attribution license which permits unrestricted use, distribution, and reproduction in any medium, provided the original work is properly cited. 